\title{
PENGEMBANGAN KAPASITAS SDM APARATUR DALAM PENYELENGGRAAN PEMERINTAHAN DESA DI DESA KENONGO KECAMATAN TULANGAN KABUPATEN SIDOARJO
}

\author{
Isnaini Rodiyah ${ }^{1}$, Hendra Sukmana ${ }^{2}$, Ilmi Usrotin Choiriyah ${ }^{3}$ \\ 1,2,3) Program Studi Administrasi Publik \\ Universitas Muhammadiyah Sidoarjo \\ *)Korespondensi: isnainirodiyah@umsida.ac.id,
}

\begin{abstract}
The village government is at the forefront of implementing public services to ensure the welfare of the community, which is a determining factor for the success of government programs. Increasing the capacity of village officials is an action to create a prosperous society. The village government must make efforts to increase the capacity of its village apparatus considering that the quality of human resources in various villages is generally still low. Therefore, the purpose of this study is to describe the development of the capacity of the apparatus in the dimension of developing the capacity of the human resources of the apparatus. Data collection in this qualitative research was carried out through participant observation, in-depth interviews, and documentation. The informants in this study were the Village Head and the Secretary of Kenongo Village, Tulangan District, Sidoarjo Regency. The data that has been collected will then be analyzed using the interactive analysis model of Miles and Huberman. The results showed that the development of human resource apparatus capacity was carried out through technical guidance from the Village Community Empowerment Service (DPMD), the implementation of technical guidance had not been accompanied by enthusiasm from the Kenongo Village government apparatus. Apparatus capacity development in the IT field has also been carried out, but not accompanied by monitoring and evaluation stages, so that IT training only evaporates without soft skills for Kenongo Village Apparatus. The findings also show that the development of the human resource capacity of village heads also needs to be improved, especially in terms of the ability to communicate with village apparatus staff to create a conducive working climate in government administration. The obstacles in carrying out the development of the capacity of the Village apparatus human resources are the lack of enthusiasm of the village apparatus in following technical guidance, the disinterest / curiosity of the village apparatus in using IT, the existence of passive village officials in planning work programs, and the morale of the apparatus is decreasing, because the salary received is used up for pay bank installments.
\end{abstract}

Article Histori:

Accepted: $27 / 3 / 2021$

Review: 30/3/2021

Publish: 30/4/2021

Keyword: capacity building, village apparatus, village administration 


\section{PENDAHULUAN}

Pemerintah desa menjadi garda paling depan yang menjalankan pelayanan publik guna menjamin kesejahteraan masyarakat yang menjadi faktor penentu keberhasilan dari program pemerintah. Pemerintah desa yang berhubungan secara langsung dengan pelayanan kepada masyarakat menjadi penentu keberhasilan program pemerintah. Pemerintah desa berada pada tingkat paling bawah dalam penyelenggaraan pemerintahan, sehingga komponen yang ada didalamnya yaitu aparatur desa memerlukan adanya profesionalisme dalam menjalankan tugas pokok dan fungsinya. Tugas pokok dan fungsi tersebut ialah mengelola pemerintahan, mewujudkan ketertiban, membantu masyarakat mengurus kebutuhan dan kepentingannya guna mewujudkan kesejahteraan dan potensi masyarakat. Aparatur desa membutuhkan adanya pengembangan kapasitas SDM untuk meningkatkan kemampuan dan ketrampilan agar tercipta hasil kinerja yang baik (Fajarwati, 2019). Meningkatkan kapasitas aparatur desa menjadi suatu tindakan untuk mewujudkan masyarakat yang sejahtera. Oleh karena itu, kapasitas aparatur di pemerintahan Desa sangatlah penting sebagai ujung tombak dalam pelayanan publik.

Aparatur desa harus memiliki pemahaman yaitu memahami tugas dan fungsi pokoknya dengan baik, kemudian keterampilan dalam melaksanakan tugas dan fungsi pokoknya serta kemampuan dalam melaksanakan tugas dan fungsi pokoknya. Pemerintah desa harus melakukan upaya untuk meningkatkan kapasitas aparatur desanya. Pengembangan kapasitas adalah suatu usaha yang bertujuan untuk mengembangkan strategi dalam menciptakan daya tanggap kinerja pemerintah yang efisien dan efektif. Efisien dalam waktu dan sumber daya, diperlukan untuk mencapai suatu hasil; efektif, berupa kesesuaian upaya dengan hasil yang diinginkan; dan daya tanggap adalah cara yang ditempuh dalam menyesuaikan kebutuhan dan kemampuan dengan tujuan. Berdasarkan pernyataan tersebut, maka pengembangan kapasitas adalah suatu usaha yang dilakukan untuk memperbaiki atau meningkatkan kualitas SDM dalam suatu organisasi. Hal ini mendorong terciptanya lingkungan kerja yang baik. (Yunus \& Sani, 2017)

Salah satu dimensi dalam pengembangan kapasitas ialah dimensi pengembangan kapasitas SDM aparatur. Dimensi pengembangan kapasitas SDM aparatur menitikberatkan pada ketersediaan tenaga yang profesional dan memiliki kemampuan secara teknis, yang dapat dilakukan dengan melakukan pelatihan, pengupahan, kondisi lingkungan kerja yang kondusif, dan rekrutmen (Yunus \& Sani, 2017). Pentingnya penyelenggaran program pengembangan kapasitas SDM agar tercapai tujuan organisasi. Pengembangan kapasitas SDM yang dilaksanakan organisasi bermanfaat bagi karyawan dalam mengembangkan karir, ketrampilan, dan ketangguhan dalam melaksanakan pekerjaan. (Labola, 2019)

Meningkatkan kapasitas aparatur desa merupakan suatu upaya untuk mempercepat terwujudnya kesejahteraan masyarakat. Namun pada kenyataannya banyak faktor yang dapat mempengaruhi kapasitas aparatur desa dalam melaksanakan tugasnya, seperti minimnya sumber akses informasi dan komunikasi. Banyak aparatur desa yang tidak diberikan informasi yang baik dan benar terkait pengelolaan manajemen desa. Sebagian besar aparatur desa tidak mengetahui dan memahami regulasi menyebabkan tugas dan tanggung jawab mereka tidak dapat dilakukan dengan maksimal. Kurangnya pemahaman mengakibatkan kondisi rentan, 
satu diantaranya kemungkinan penggunaan anggaran dana tidak sesuai peruntukan, bahkan berujung penyelewengan dana desa. Selain itu, permasalahan-permasalahan lainnya yakni banyaknya aparatur desa berusia lebih dari 50 tahun ke atas yang tidak mengetahui tugas pokok dan fungsi pekerjaan, minimnya pengetahuan dan pemahaman dalam penggunaan informatika dan teknologi (IT), pembangunan fisik desa kurang maksimal, dan potensi desa belum dimanfaatkan secara maksimal.

Upaya yang dilakukan dalam meminimalisir faktor-faktor dan permasalahan sebagaimana dijelaskan di atas yakni melalui pengembangan kapasitas SDM aparatur desa. Pengembangan kapasitas sumber daya manusia dalam kaitannya dengan profesionalisme aparatur pemerintah merupakan aspek penting yang harus diperhatikan dalam pengembangan sumber daya manusia di lingkungan pemerintahan. Pengembangan kapasitas SDM aparatur merupakan salah satu upaya untuk meningkatkan ketrampilan dan pengetahuan agar menjadi profesional melaksanakan tugasnya untuk mendukung pencapaian tujuan penyelenggaraan daerah utonom baru. Semua penguatan aparatur sumber daya manusia diarahkan untuk mencapai pembangunan dan pelayanan yang optimal kepada masyarakat. (Darmi \& Suwitri, 2017)

Pengembangan kapasitas SDM aparatur dapat dilakukan melalui pengadaan pelatihan Aparatur desa berperan penting dalam mendukung kemajuan pemerintahan desa. Dalam menjalankan administrasi desa yang efektif memerlukan adanya bimbingan teknis yang ditujukan untuk aparatur desa. Tujuan pelaksanaan bimbingan teknis ini ialah pelaksanaan tugas dan kewajiban dalam hal melayani masyarakat dapat dijalankan dengan baik oleh aparatur desa sebagaimana tertuang pada UndangUndang No 6 Tahun 2014 tentang Desa pasal 112. Tujuan dilaksanakannya pembinaan administrasi desa ialah untuk memperbaiki sistem administrasi pemerintahan desa yang menyediakan informasi untuk pemerintah dalam menjalankan aktivitas pembangunan (Atika et al., 2018). Pentingnya pengembangan kapasitas SDM aparatur melalui pelatihan pernah diteliti oleh Fajarwati (2019) dan Aminah dan Susanto (2018). Fajarwati (2019) menyebutkan bahwa perlunya pengembangan kapasitas SDM aparatur dengan menyelenggarakan pelatihan dan sosialisasi secara rutin mengenai tertib administrasi dalam pelayanan di desa dan kemampuan memahami hal teknis penunjang (mengoperasikan komputer).

Kemudian pada penelitian Aminah dan Susanto (2018) menyebutkan bahwa pengembangan kapasitas dapat dilakukan melalui penambahan intensitas, memperpanjang waktu dan pedalaman materi, disertai praktik secara teknis dalam perencanaan pembangunan desa dan pengelolaan keuangan dalam diklat.

Berdasarkan ulasan permasalahan sebelumnya, maka tujuan dari penelitian ini adalah untuk mendeskripsikan pengembangan kapasitas aparatur desa Kenongo Kecamatan Tulangan Kabupaten Sidoarjo pada dimensi pengembangan kapasitas SDM aparatur beserta hambatanhambatan yang dilaluinya. Beberapa kajian penelitian terdahulu menyatakan bahwa kualitas sumber daya aparatur desa dinilai masih rendah (Mangindaan \& Manossoh, 2018; Rimadani et al., 2019; Salim et al., 2017), sehingga permasalahan penelitian ini penting untuk dikaji lebih lanjut. 


\section{KAJIAN LITERATUR}

Pengembangan kapasitas adalah suatu usaha yang dilakukan untuk memperbaiki atau meningkatkan kualitas SDM dalam suatu organisasi. Hal ini mendorong terciptanya lingkungan kerja yang baik. (Yunus \& Sani, 2017) Salah satu dimensi dalam pengembangan kapasitas ialah dimensi pengembangan kapasitas SDM aparatur.

Dimensi pengembangan kapasitas SDM aparatur menitikberatkan pada ketersediaan tenaga yang profesional dan memiliki kemampuan secara teknis, yang dapat dilakukan dengan melakukan pelatihan, pengupahan, kondisi lingkungan kerja yang kondusif, dan rekrutmen (Yunus \& Sani, 2017). Pentingnya penyelenggaran program pengembangan kapasitas SDM agar tercapai tujuan organisasi. Pengembangan kapasitas SDM yang dilaksanakan organisasi bermanfaat bagi karyawan dalam mengembangkan karir, ketrampilan, dan ketangguhan dalam melaksanakan pekerjaan. (Labola, 2019)

\section{METODE PENELITIAN}

Penelitian kualitatif ini dilaksanakan di Desa Kenongo Kecamatan Tulangan Kabupaten Sidoarjo. Pengumpulan data primer dilakukan melalui observasi partisipan, wawancara mendalam, dan dokumentasi. Informan dalam penelitian ini terdiri dari Kepala Desa dan Sekretaris Desa. Pertanyaan wawancara yang diajukan kepada informan ialah mengenai pengembangan kapasitas SDM aparatur Desa Kenongo khususnya dalam hal pengembangan kapasitas SDM aparatur. Sebelum wawancara dilaksanakan, peneliti melakukan observasi partisipan untuk mengetahui permasalahan yang dialami oleh Pemerintah Desa Kenongo Kecamatan Tulangan.
Data yang sudah terkumpul akan diolah dengan model analisis interaktif Miles dan Huberman. Tahapan model analisis ini antara lain: mengumpulkan data, mengurangi/ mereduksi data, menyajikan data, dan menyusun kesimpulan/verifikasi (Sugiyono, 2017:133). Berdasarkan model analisis ini, jawaban-jawaban informan akan disajikan berupa narasi guna mengetahui secara mendalam terkait permasalahan pengembangan kapasitas di Desa Kenongo. Jawaban-jawaban informan akan dikaji lebih lanjut untuk mengetahui sesuai atau tidaknya jawaban tersebut dengan permasalahan yang akan ditelaah dalam penelitian ini, apabila dirasa belum sesuai, maka peneliti akan melakukan pengumpulan data kembali. Tahap tersebut disebut sebagai tahap reduksi data. Tahap selanjutnya ialah penyusunan kesimpulan atau verifikasi. Adanya kesimpulan ini dapat mempermudah pembaca memahami permasalahan pengembangan kapasitas SDM di Desa Kenongo Kecamatan Tulangan Kabupaten Sidoarjo.

Pengembangan kapasitas merupakan sebuah proses dan upaya yang berkelanjutan dalam mengembangkan kemampuan, keterampilan, potensi juga bakat dari setiap individu, kelompok dan organisasi yang bertujuan untuk individu, kelompok dan organisasi dapat bertahan dalam menangani perubahan yang cepat dan tiba-tiba. Artinya pengembangan kapasitas ini tidak berangkat dari nol melaikan dari kemampuan indvidu, kelompok/ organisasi yang telah ada lalu melalui proses pembelajaran maupun hal lain yang berkaitan dengan pengembangann kapasitas, diharapkan dapat meningkatkan kualitas individu, kelompok maupun organisasi agar bisa bertahan dalam kondisi lingkungan yang terus menerus mengalami perubahan (Kandiyah \& Diwanti, 2020). Konsep 
pengembangan kapasitas SDM aparatur yang menjadi fokus dalam penelitian ini ialah mengenai pengembangan kapasitas SDM aparatur. Pengembangan kapasitas SDM aparatur merupakan suatu kegiatan yang dilaksanakan oleh suatu organisasi yang bertujuan untuk mengembangkan kemampuan karyawan-karyawannya. Melalui kegiatan ini, karyawan akan mampu menyelesaikan permasalahan yang dihadapi dalam melaksanakan pekerjaan dengan sebaik mungkin. (Sedarmayanti, 2017)

Secara umum, tujuan dari pengembangan sumber daya manusia (SDM) antara lain yaitu 1) mengembangkan karyawan sesuai kemampuan, ketrampilan, dan karakteristiknya; 2) mengembangkan karir karyawan; 3) mengelola karyawan sebagai bagian dari organisasi melalui pengukuran kinerja, pembagian pekerjaan, dan sebagainya; 4) memperoleh sumber daya manusia sebagaimana kebutuhan organisasi; 5) penyelarasan antara tata Kelola dan ketentuan organisasi sebagai pencegah risiko maupun faktor eksternal (Labola, 2019).

\section{HASIL DAN PEMBAHASAN}

Aparatur desa menjadi garda paling depan yang menjalankan pelayanan publik guna menjamin kesejahteraan masyarakat yang menjadi faktor penentu keberhasilan dari program pemerintah. Meningkatkan kapasitas aparatur desa menjadi suatu tindakan untuk mewujudkan masyarakat yang sejahtera. Aparatur desa dituntut untuk mempunyai kemampuan dan selalu berusaha meningkatkan kapasitas agar bisa menyesuaikan dengan tuntutan perubahan lingkungan sebagai konsekuensi adanya perubahan kebijakan yang ada. Pengembangan kapasitas SDM aparatur desa pada penelitian ini berfokus pada dimensi pengembangan kapasitas SDM aparatur, karena kualitas SDM aparatur masih dinilai rendah. Pada penelitian ini juga akan dikaji mengenai hambatanhambatan yang dialami pemerintah Desa Kenongo dalam melaksanakan pengembangan kapasitas SDM aparaturaparaturnya.

\section{Pengembangan Kapasitas SDM Aparatur Desa Kenongo.}

Pengembangan kapasitas aparatur Pemerintahan Desa di Desa Kenongo Kecamatan Tulangan Kabupaten Sidoarjo melalui bimbingan teknis pada dasarnya sudah dilaksanakan oleh Dinas Pemberdayaan Masyarakat dan Desa (DPMD) Kabupaten Sidoarjo. Bimbingan teknis ini diharapkan dapat disesuaikan dengan kebutuhan untuk meningkatkan kapasitas aparatur desa lembaga desa dalam melaksanakan program desa. Pelaksanaan bimbingan teknis bagi aparatur Desa Kenongo selama ini hanya sebatas bimbingan secara umum dan belum termasuk ke dalam pendampingan secara teknis pelaksanaannya, sehingga belum mampu membantu menyelesaikan permasalahan dalam melaksanakan pekerjaan sehari-hari. Bimbingan teknis ini tidak disertai dengan adanya semangat dari aparatur desa. Kebanyakan aparatur desa mengikuti bimbingan teknis hanya sekedar formalitas saja.

Pengembangan sumber daya aparatur desa Kenongo merupakan cara yang dilakukan untuk meningkatkan kualitas aparatur desa Kenongo. Pengembangan kapasitas SDM aparatur Desa Kenongo dilaksanakan melalui bimbingan teknis. Tujuan dilaksanakannya bimbingan teknis ini adalah untuk mengembangkan kapasitas SDM aparatur desa Kenongo agar mampu menciptakan pemerintahan desa yang efektif. Sebagaimana teori yang mengemukakan bahwa bimbingan teknis 
yang dilakukan dalam jangka waktu tertentu bertujuan agar dapat mewujudkan pemerintahan yang efektif. Pernyataan tersebut menegaskan bahwa dalam mewujudkan pemerintahan desa yang efektif dibutuhkan aparatur desa yang memiliki profesionalisme dalam bekerja. Berdasarkan undang-undang nomor 6 tahun 2014 yang menjelaskan bahwa asas profesional merupakan salah satu asas penyelenggaraan pemerintahan di tingkat desa, sehingga aparatur desa yang membantu kepala desa harus mampu bekerja secara profesional dalam melayani masyarakat (Alam, 2017:67-68)

Bimbingan teknis yang ditujukan kepada aparatur desa Kenongo menjadi wadah bagi aparatur untuk belajar mengatasi permasalahan selama melaksanakan pekerjaannya agar produktivitas kerjanya meningkat. Sebagaimana penelitian terdahulu yang menyatakan bahwa bimbingan teknis pada dasarnya merupakan proses pelatihan karyawan. Organisasi perlu mengevaluasi produktivitas dan bimbingan teknis. Keseluruhan karyawan perlu dibimbing sampai akhir. Melalui bimbingan teknis ini, ketrampilan dan kemampuan karyawan dapat ditingkatkan. Karyawan yang memiliki ketrampilan dan kemampuan yang bagus serta adanya motivasi kerja sangat menentukan produktivitas kerjanya (Bariqi, 2018). Melaksanakan bimbingan teknis bagi karyawan dapat meningkatkan produktivitas kerjanya. Selain itu, bimbingan teknis ini akan meningkatkan kemampuan karyawan disertai dengan adanya peningkatan kedisiplinan kerja yang mampu mewujudkan individu yang profesional dalam melaksanakan perkerjaan terkait kepentingan organisasi. (Alam, 2017:37)

Pengembangan kapasitas SDM aparatur desa Kenongo melalui bimbingan teknis belum berjalan sebagaimana mestinya. Bimbingan teknis yang dilaksanakan hanya sebatas bimbingan secara umum saja dan belum termasuk dalam pendampingan teknis pelaksanaannya. Padahal didasarkan penelitian terdahulu, pengembangan kapasitas SDM aparatur melalui pemberian pelatihan (training) atau bimbingan teknis itu harusnya mecakup pengembangan pengetahuan, ketrampilan, potensi, kepribadian, modal, dan etos kerja dalam mendukung terciptnya administrasi desa yang tertib. Pengembangan kapasitas SDM aparatur desa harus dilaksanakan supaya tercapainya tujuan organisasi (Fajarwati, 2019). Pengembangan kapasitas SDM aparatur melalui bimbingan teknis penting dilaksanakan, karena skill karyawan mengenai pengetahuan sesuai jabatan, tugas pokok dan fungsinya sebagai aparatur pemerintah dapat berkembang. Keberadaan SDM aparatur menjadi penting dalam hal menyelesaikan keseluruhan kepentingan organisasi, khususnya pada era perkembangan ilmu pengetahuan dan teknologi saat ini. Oleh karena itu, SDM aparatur mutlak untuk dikelola supaya kualitasnya bisa meningkat sesuai bidang pekerjaannya. (Salim et al., 2017)

Pengembangan kapasitas SDM aparatur desa tidak hanya berhenti pada bimbingan teknis saja, melainkan juga ada pelatihan terkait teknologi dan informasi (IT). Pelatihan IT sebagai wujud kegiatan pengembangan kapasitas SDM dalam hal kemampuan aparatur desa di bidang teknologi dan informasi (IT) sudah dilaksanakan, namun pelaksanaannya menjadi kurang optimal dikarenakan pada pelatihan ini tidak dibarengi dengan tahapan monitoring dan evaluasi. Disamping itu tingkat ketertarikan dan curiosity yang rendah dari aparatur terhadap informasi teknologi sehingga 
pelatihan IT tidak berdampak pada pengemabangan kemampuan aparatur Desa Kenongo. Karena itu ingga saat inikemampuan IT aparatur desa masih menjadi masalah utama pengoperasional teknologi, sehingga para aparatur kurang maksimal dalam menjalakan tugas dan fungsinya sebagai penyelenggara pelayanan public, utamanya pelayanan adminitrasi di desa Kenongo.

Pelaksanaan pengembangan kapasitas SDM aparatur desa melalui pelatihan IT tidak didasari dengan adanya softskill dari aparatur desa itu sendiri, sehingga dalam pelaksanaan pekerjaan menjadi tidak efisien mengingat IT ini diperlukan dalam menyediakan data informasi desa ke tingkat kecamatan Tulangan dan kabupaten Sidoarjo. Aparatur desa Kenongo yang notabene tidak memiliki ketertarikan dalam menggunakan IT menjadikan desa menjadi kurang maju dalam hal update informasi. Hasil ini tidak sejalan dengan penelitian yang menemukan bahwa teknologi informasi (IT) saat ini telah berkembang pesat sampai ke pelosok desa. IT tidak lagi menjadi hal yang asing bagi masyarakat desa, sehingga pemerintah desa menggunakan IT untuk mendukung keefektifan layanan publik (Purba, 2018). Selain dapat meningkatkan kualitas pelayanan, IT dapat berfungsi sebagai media pengolahan informasi dalam merancang pembangunan, mengambil keputusan, memonitoring, memudahkan dalam menyusun perencanaan, dan evaluasi hasil pembangunan (Mayowan, 2017). Keberhasilan pemanfaatan TIK perlu ditunjang sarana dan prasarana yang baik termasuk sumber daya manusia yang profesional. Di samping itu, perlu adanya pengembangan skill karyawan di lingkup pemerintah desa agar memiliki skill sesuai yang diperlukan. (Purba, 2018)
Pengembangan kapasitas SDM tidak hanya ditujukan pada staff aparatur desa saja melainkan untuk seluruh elemen pemerintah desa termasuk Kepala Desa, utamanya dalam hal pengembangan kemampuan berkomunikasi terhadap staff aparat desa untuk menciptakan suasana iklim kerja yang kondusif dalam penyelenggraan pemerintahan, karena lingkungan yang demikian dapat terwujud jika terdapat pemimpin yang mampu memahami, melindungi, mengarahkan bawahannya dalam melayani masyarakat. Hal ini dapat dilaksanakan dengan melakukan pekerjaan secara profesional sesuai tugas pokoknya dan lebih mementingkan kepentingan masyarakat secara umum. Kurangnya kemampuan komunikasi Kepala Desa dengan aparaturaparaturnya juga menjadi hal yang perlu diperhatikan dalam melaksanakan pengembangan kapasitas SDM aparatur. Pada dasarnya komunikasi yang dilakukan kepala desa melibatkan seluruh elemen pemerintahan desa, kepala desa dan perangkat desa merupakan salah satu prasyarat untuk keberhasilan proses pembangunan dan merupakan langkah maju untuk meningkatkan kemakmuran desa dan kesejahteraan masyarakat. Melalui komunikasi akan terjadi interaksi yang dapat menyamakan persepsi, sehingga terbangunnya kerjasama antara pimpinan dengan perangkat desa. (Permada, 2018)

SDM aparatur desa Kenongo menjadi prioritas utama pemerintah desa yang membutuhkan upaya pengembangan kapasitas agar tercipta SDM yang berkualitas dan memiliki profesionalisme yang tinggi. Meninjau pelaksanaan bimbingan teknis dan pelatihan IT yang diselenggarakan oleh Dinas Pemberdayaan Masyarakat dan Desa (DPMD) Kabupaten Sidoarjo, dapat dikatakan bahwa pengembangan kapasitas SDM aparatur 
desa belum dilaksanakan secara optimal, sehinga diperlukan kerjasama dengan pemerintah daerah Kabupaten Sidoarjo untuk menyusun ide baru dalam melaksanakan pembekalan aparatur desa yang memiliki profesionalisme dalam menjalankan tugas-tugas sesuai ketentuan perundang- undangan (Alam, 2017:115).

\section{Hambatan Pengembangan Kapasitas SDM Aparatur Desa Kenongo}

Hambatan-hambatan yang dihadapi dalam pengembangan kapasitas SDM aparatur Desa Kenongo antara lain (1) Kurangnya antusiasme aparatur desa dalam mengikuti bimbingan teknis yang dilaksanakan Dinas Pemberdayaan Masyarakat dan Desa (DPMD) secara serius. Hal ini terlihat dari minimnya feedback positif dari mayoritas aparatur desa terhadap kegiatan bimbingan teknis yang dilaksanakan. Sebagian besar hanya mengikuti sebagai kegiatan formalitas mendapat honorarium transportasi. Hal ini, berakibat kegiatan bimbingan teknis belum mampu meningkatkan kapasistas aparatur pemerintah desa. (2)Ketidaktertarikan atau curiosity aparatur desa dalam menggunakan teknologi dan informasi (IT). Dalam menciptakan profesionalisme pemerintah diperlukan adanya pengembangan kemampuan aparatur desa dalam melaksanakan pekerjaan menggunakan teknologi informasi, karena IT ini dapat dijadikan media perbaikan administrasi desa. Terdapat beberapa kelemahan pada administrasi desa yaitu terkait proses update data desa yang tidak sesuai dengan data di tingkat kecamatan maupun kabupaten. Berdasarkan UU nomor 14 tahun 2008 pasal 2 ayat 1, keseluruhan informasi publik harusnya bersifat transparan dan seluruh pengguna informasi tersebut dapat mengaksesnya. Adanya penerapan IT di lingkup pemerintah desa dapat menciptakan data dengan informasi yang sama baik diakses di tingkat kecamatan maupun kabupaten. Adanya kecanggihan teknologi ini tentu membutuhkan skill aparatur desa yang mumpuni. (Wicaksono \& Riyadh, 2018)

(3) Terkadang masih ada aparatur desa yang pasif dalam perencaaan program kerja yang dapat memicu terhambatnya waktu penyelesaian pekerjaan. Peran aktif seluruh aparatur desa menjadi penentu tercapainya keberhasilan suatu program. Pelaksanaan program pemerintah menjadi kurang efektif bila tidak disertai kerjasama yang harmonis antar aparatur desa. Kerjasama ini tidak dapat terwujud tanpa adanya kesadaran aparatur desa untuk terlibat secara aktif dalam program pemerintah. (4) Semangat kerja aparatur semakin menurun, karena gaji bulanan habis dipakai membayar angsuran Bank. Hal ini dapat berdampak pada pelaksanakan pengembangan kapasitas SDM aparatur yang kurang efektif.

\section{PENUTUP}

Pengembangan kapasitas SDM aparatur Desa Kenongo yang difokuskan pada pengembangan kapasitas SDM aparatur melalui bimbingan teknis dan pelatihan IT belum dilaksanakan sebagaimana mestinya. Pelaksanaan bimbingan teknis belum optimal, karena bimbingan teknis yang dilaksanakan tidak termasuk ke dalam pendampingan secara teknis pelaksanaannya, sehingga aparatur desa masih mengalami kesulitan dalam menyelesaikan permasalahan dalam pekerjaan. Untuk pelaksanaan pelatihan IT juga dirasa belum optimal, karena kebanyakan aparatur desa masih memiliki pengetahuan dan pemahaman yang minim terkait IT dan dalam pelaksanaannya tidak disertai adanya monitoring dan evaluasi. Pengembangan kapasitas SDM Kepala Desa 
perlu adanya ditingkatkan, terutama dalam hal kemampuan berkomunikasi terhadap staff aparat desa untuk menciptakan suasana iklim kerja yang kondusif dalam penyelenggraan pemerintahan.

Hambatan dalam melaksanakan pengembangan kapasitas SDM aparatur Desa Kenongo yang difokuskan pada pengembangan kapasitas SDM aparatur ialah kurangnya kesadaran dan antusias aparatur desa dalam mengikuti bimbingan teknis, ketidaktertarikan aparatur desa dalam menggunakan IT, adanya aparatur desa yang pasif dalam perencaaan program kerja, serta semangat kerja aparatur semakin menurun, karena gaji bulanan habis dipakai membayar angsuran Bank.

Pola pengembangan kapasitas aparatur Desa Kenongo yang dapat direkomendasikan dalam kajian ini adalah perlu adanya pendidikan dan pelatihan terkait dengan kemampuan secara teknis kegiatan penyelenggaraan pemerintahan desa, baik yang bersifat administratif maupun manajemen, serta kepemimpinan, khususnya bagi Kepala Desa. Disamping itu, sangat penting untuk diadakan pelatihan peningkatan pemahaman serta kemampuan mengopersionalkan IT (informasi teknologi) agar dapat meningktakan kualitas pelayanan kepada masyarakat. Kegiatan yang juga tidak kalah penting bahwa kegiatan pelatihan dan bimbingan harus ada pendampingan, monitoring dan evaluasi agar kegiatan berjalan efektif dan sesui dengan rencana awal. Sedangkan beberapa upaya yang dapat dilaksanakan sebagai solusi dari hambatan yang terjadi dalam pengembangan kapasitas SDM aparatur, antara lain: 1) memberikan teguran kepada aparatur desa agar mengikuti bimbingan teknis; 2) merangkul semua aparatur desa untuk terlibat secara aktif dalam perencanaan program kerja; 3) meningkatkan pengetahuan dan pemahaman IT aparatur desa dengan mengadakan pelatihan IT yang selalu dimonitoring dan dievaluasi pelaksanaannya; 4) pemberian reward berupa bonus atau insentif bagi aparatur yang memiliki prestasi kerja yang bagus.

\section{DAFTAR PUSTAKA}

Alam, H. V. (2017). Pengembangan sumber daya aparatur desa. (Gorontalo: Ideas Publishing).

Aminah, S. and Sutanto, H. P. (2018). Analisis tingkat kapasitas aparatur pemerintah desa di kabupaten Bogor. Matra Pembaruan 2, 3, 149-160.

Atika, N., Ati, N. U., and Hayat. (2018). Peningkatan kinerja aparatur desa dalam melaksanakan tugas administrasi desa melalui pendidikan dan pelatihan. Civil Service 12, 1, 33-39.

Bariqi, M. D. (2018). Pelatihan dan pengembangan sumber daya manusia. Jurnal Studi Manajemen dan Bisnis 5, 2, 64-69.

Darmi, T. \& Suwitri, S. (2017). Strengthening the capacity of human resources apparatus in the implementation of new autonomous regions. European Journal of Social Sciences 55, 4, 427-438.

Fajarwati. N. (2019). Pengembangan kapasitas aparatur pemerintah desa dalam rangka mewujudkan good governance. Jurnal Wacana Kinerja 22, 2, 219-234.

Kandiyah, N. and Diwanti, D. P. (2020). Pengaruh capacity building terhadap kinerja karyawan perbankan syariah (studi kasus pada bank muamalat daerah Yogyakarta). JMBA 7, 1, 10- 30.

Labola, Y. A. (2019). Konsep pengembangan sumber daya manusia berbasis kompetensi, bakat dan ketahanan dalam organisasi. Jurnal Manajemen \& Kewirausahaan 7, 1, 28-35. 
Mangindaan, J. V. and Manossoh, H. (2018). Kualitas sumber daya manusia pemerintah desa dalam pengelolaan dana desa yang bersumber dari anggaran pendapatan dan belanja negara di Kecamatan Tabukan Utara Kab. Kepulauan Sangihe. Jurnal LPPM Bidang EkoSosBudKum 4, 1, 35-49.

Mayowan, Y. (2017). Penerapan teknologi informasi dan komunikasi di desa (studi kasus di kabupaten Lamongan). Profit (Jurnal Administrasi Bisnis) 10, 1, 14-23.

Permada, O. (2018). Komunikasi kepemimpinan kepala desa dalam pembangunan desa Simandolak kecamatan benai kabupaten Kuantan Singingi tahun 2013-2018. JOM FISIP 5, 1, 1-14.

Purba, S. (2018). Pemanfaatan teknologi informasi dan komunikasi pada lingkungan pemerintahan desa di kecamatan Sungai Pandan. Jurnal Bisnis dan Pembangunan 7, 1, 41- 44.

Rimadani, R., Sarwono., and Sentanu, I. G. E. P. S. (2019). Kualifikasi pendidikan nonformal aparatur pemerintah desa: strategi dan tantangan. Jurnal Administrasi Pendidikan 26, 2, 336-344. Salim, A., Rivai, A., and Mufti, M. I. (2017). Pengembangan sumber daya aparatur sipil negara pada kantor pemberdayaan masyarakat dan pemerintahan desa Kabupaten Parigi Moutong. E Jurnal Katalogis, 5, 11, 111-115.

Sedarmayanti. (2017). Perencanaan dan pengembangan sumber daya manusia. (Bandung: PT Refika Aditama).

Sugiyono. (2017). Metode penelitian kuantitatif, kualitatif, dan r\&d. (Bandung: Alfabeta, CV). Wicaksono, A. E. and Riyadh, A. (2018). Kemampuan aparatur desa dalam pemahaman teknologi informasi dan komunikasi menuju electronic desa (e-desa) pada kantor desa Kedungbocok kecamatan Tarik kabupaten Sidoarjo. Jurnal Kebijakan dan Manajemen Publik 6, 2, 137-148.

Yunus, M. and Sani, K. R. (2017). The capacity building of local government in Sanjai village, Sinjai regency. MIMBAR $33,2,245-252$. 